\title{
How Mortgage Interest Rates and Salaries Affect the Mortgage Debt
}

\author{
Chief Assist. Prof. Dr. Svetlana Todorova \\ University of Economics - Varna, Varna, Bulgaria \\ svetlana.todorova@ue-varna.bg \\ Chief Assist. Prof. Dr. Dimitria Karadimova \\ University of Economics - Varna, Varna, Bulgaria \\ d.karadimova@ue-varna.bg
}

\begin{abstract}
This paper explores the relationship between household mortgage debt and mortgage interest rate and salary in Bulgaria. The monthly data in this research paper is from January 2007 to June 2020, from existing official sources NSI (National Statistical Institute) and BNB (Bulgarian National Bank). The chosen initial period is related to the beginning of the Monetary Board and the macroeconomic stability of the country after the Board. The research methodology includes correlation, regression analysis and related tests of statistical hypotheses. Based on the results, we derive the estimated regression equation that can be used to explain the impact of changes in independent variables on the dependent variable and to make predictions. We found that mortgage debt is positively associated with salary and negatively associated with mortgage interest rate.
\end{abstract}

Keywords: Mortgage Debt, Mortgage Interest Rate, Salary, Multiple Regression

JEL Code: E19, G21, R21

DOI: https://doi.org/10.36997/IJUSV-ESS/2020.9.1.63

\section{Introduction}

Often in economic theory the relationship between variables may offer the evidence about two-way direction of true causality. On one hand, mortgage debt depend on the macroeconomic stability in the country, household incomes and savings, interest rates, etc. On the other hand, mortgage debt can be considered as a factor that affects the housing prices, household consumption and saving. The mortgage debt is directly related to the cyclical nature of the economy. It can cause a financial crisis. This research examines only one-way direction of the causality. Mortgage debt is the dependent variable, and as independent variables are the average salary and mortgage interest rate.

The average salary and mortgage interest rates are the factors that influence the desire, ability and choice of a suitable time to buy a home. Increasingly, households in Bulgaria prefer to invest their savings in buying homes. The grow of the activity on the real estate market in Bulgaria can be connected with several tendencies: 1) the average salary increases; 2) there is a tendency to decrease the interest rates on deposits and it turns out to be economically unprofitable for households to invest their free cash in banks; 3) mortgage interest rates show a steady downward trend. The dynamics of mortgage debt and the factors that impact its growth have a direct connection with the cyclical economic situation in the country. The global financial crisis started with high-risk mortgages in the United States.

The object of the research is the mortgage debt, and the subject - the impact of the factors determined the mortgage debt. The empirical study covers the period from January 2007 to June 2020. The chosen initial period is related to the beginning of the Monetary Board and the macroeconomic stability of the country after the Board. The research methodology includes correlation, regression analysis and related tests of statistical hypotheses.

\section{Literature Review}

Mortgage debt impacts the household consumption and saving. The researchers (Fan and Yavas, 2020) found that households with a mortgage spend a larger share of their income on mortgage payments and spend less of their income on consumption. According to them the 
government policy of decreasing the maximum loan-to-value ratio has a significant impact on the consumption behavior of households. The recent study show that an increase in mortgage payment, leads households to work and earn more and around $35 \%$ of the increase in payment is covered with the increase in income, including spousal labor supply, change of job or additional income from after-hours work (Zator, 2020). On the other hand, mortgage debt is also important for monetary policy since the size and growth rate of mortgage debt has implications for the effectiveness of monetary policy (Calza, Monacelli and Stracca, 2013). Mortgages are a major portion of bank assets. And the financial crisis that began in 2007 has made it abundantly clear that problems in mortgage lending have the potential to destabilize the financial system and the economy (Campbell, 2013).

According to the monetary theory, the causes of cyclical fluctuation in economics are based on trends of the macrocosmic indicators such as loans, money, prices and interest rates. The authors of these theories saw the causes of economic crises in the changes of money supply. The increase in mortgage loans is associated with the beginning of the global financial crisis. On the other hand, mortgage loans can also be considered as a factor in house price rising. Hristo Mavrov (Mavrov, 2011) seeks an answer to the questions: is there a price shock in the real estate market in Bulgaria in the period 1998 - 2010 and what reasons are for that? The author identifies a price shock - rapid price growth in 2003 - 2009, followed by a period of dramatic decline, making a comparative analysis of indicators with other countries, included also the United Kingdom. D. Karadimova (Karadimova, 2018) considered mortgage loans as a factor for the housing price rising. Using correlation and cross-spectral analysis, measured the straight and direction of the relationship and components, she found that there is a strong relationship between mortgage loans and housing prices.

V. Milinov, P. Angelov and S. Zarkova (Milinov, Angelov and Zarkova, 2018) grouped the countries of the European Union according to variety indicators for the mortgage market, the real estate market and the economic potential of the European Union members. They focused the main factors of the demand and supply that determined the real estate market in Bulgaria and Greece. The researchers applied a multivariate comparative analysis based on Helving's taxonomic model to make an ascending or descending order of the countries. Based on the empirical results, they found that the countries with a developed mortgage market are Netherlands, Denmark, Sweden and Germany, because of the higher mortgage loans.

The dynamics of new household loans in Bulgaria, based on a monthly data, shows that the consumer and housing (mortgage) loans followed the same trend. Both loans form a major part of the household debt (Figure 1).

There are three distinguished periods:

- 2007 - 2008 - the period of the growth of GDP and FDI in the country. In this period the household lending increased. The financial situation of households has improved and, together with the stable monetary policy of the banks, it has led the growth of investment in housing. The new housing (mortgage) loans are experiencing with the highest growth rates. They reached the highest levels at the end of 2019.

- In 2009, housing (mortgage) loans fell significantly due to the financial and economic crisis. There is a shrinking GDP and household income. During this period the bad and restructured loans increased. After that, from 2010 to 2015, the new housing loans were around the average level for the period.

- Housing (mortgage) loans increased from 2016 to 2019. The main factors for the growth of the housing loan demand are the lower interest rates and the macroeconomic stability of the country. In 2020, banks reported a significant reduction in housing loans demand, because of the COVID-19 pandemic. Uncertainty regarding employment and household income is deepening. During the same period, there was a significant bank restriction for housing loans. 
(BGN million)

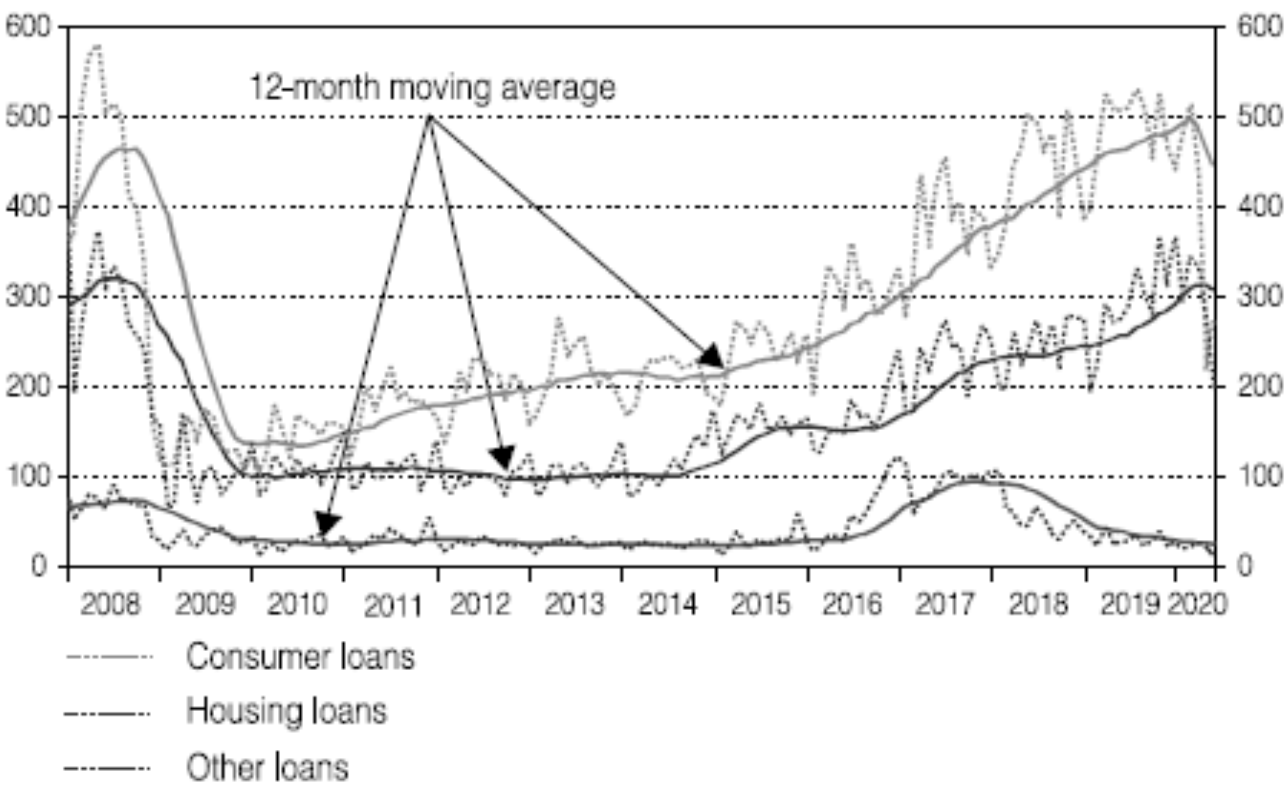

Figure 1. New Household Loans (Monthly Volumes)

Source (Bulgarian National Bank, 2020):

http://bnb.bg/bnbweb/groups/public/documents/bnb_publication/pub_ec_r_2020_02_en.pdf

Mortgage interest rate and salary, the largest portion of the household income, are the most important factors influencing the decision to purchase a house. The average salary in Bulgaria increased throughout the research period. The highest growth rates of the salary are observed at the time of the highest new housing loans in 2008 - 2009. The trend of the salary is opposite of the mortgage interest rate trend (Figure 2).

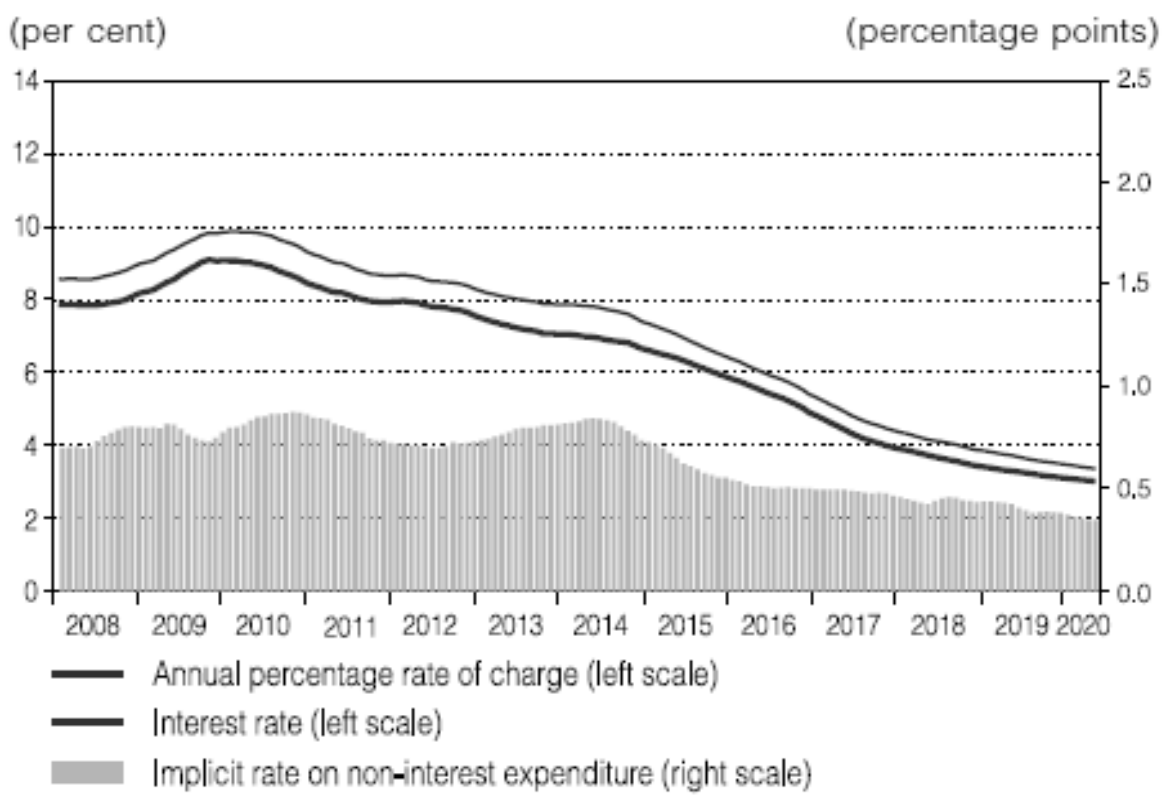

Notes: Interest rates in all maturities and currencies are weighted by the relevant volumes of new loans for a 12-month period. Implicit per cent is the difference between the APRC and the relevant interest rates and reflects the approximate per cent of all non-interest service charges on loans (including fees and commissions).

Figure 2. Interest Rates and Annual Percentage Rate of Charges on New Housing Loans Source (Bulgarian National Bank, 2020):

http://bnb.bg/bnbweb/groups/public/documents/bnb_publication/pub_ec_r_2020_02_en.pdf 
Mortgage interest rates increased until 2010. In the last quarter of 2010, mortgage interest rates decreased. This trend persisted until the end of the period. The lower mortgage interest rates in recent period of time have led to an increase in the mortgages of households. Significantly low interest rates on deposits also contribute to this fact.

\section{The Model Setting}

The empirical approach of the paper aims to explore the relationship between mortgage debt and two independent variables - mortgage interest rate and salary. We use monthly data from January 2007 to June 2020. The data used in this study are collected over the time and the value of dependant variable at time " $t$ " is to be related to the value of previous time period " $t-1$ ". To avoid the serial correlation which is presented in the data we include in the model one more independent variable - time. Because the time-series data are consecutive, the "time" can be entered as numbers from 1 to 160 (observed numbers of months). The variables employed in the model are described as follows:

Mortgage - Mortgages Debt in million leva;

Interest_Rate - Effective Annual Mortgage Interest Rate in \% ;

Salary - Average Monthly Salary in leva;

Time - the time period.

We used the existing official sources of data from NSI (National Statistical Institute. Infostat, 2020) and BNB (Bulgarian National Bank, 2020).

To study the relationship between household mortgages and independent variables we used the following multiple regression model:

$$
\text { Mortgage }=\beta_{0}+\beta_{1} \text { Interest_Rate }+\beta_{2} \text { Salary }+\beta_{3} \text { Time }+\varepsilon
$$

where Mortgage is the dependant variable, Interest_Rate, Salary, and Time are the independent variables, and $\varepsilon$ is the random error term. The coefficients $\beta_{0}, \beta_{1}, \beta_{2}$, and $\beta_{3}$ are the unknown parameters to be estimated.

\section{Computational Model and Empirical Results}

To estimate the multiple regression model (1) we used SPSS. The sample regression equation for the multiple regression model is denoted as

$$
\text { Mortgage }=b_{0}+b_{1} \text { Interest_Rate }+b_{2} \text { Salary }+b_{3} \text { Time }
$$

where $b_{0}, b_{1}, b_{2}$, and $b_{3}$ are the point estimates of $\beta_{0}, \beta_{1}, \beta_{2}$, and $\beta_{3}$.

First, we estimated the regression model included all observations. Based on a Studentized residual plot, we found that there are some values that are around \pm 3 standard deviation reference lines and some - go beyond \pm 3 reference lines, which means that these values are outliers and we must removed them. Second, we estimated the regression model with removed extreme values (outliers). The new estimated model included 145 observations. The regression results are in Table 1, Table 2, Table 3, Figure 3, Figure 4, Figure 5, Figure 6, and Figure 7 (SPSS output):

Table 1.

Model Summary

\begin{tabular}{|l|c|r|r|r|}
\hline Model & R & R Square & $\begin{array}{c}\text { Adjusted R } \\
\text { Square }\end{array}$ & $\begin{array}{c}\text { Std. Error of } \\
\text { the Estimate }\end{array}$ \\
\hline 1 & $.983^{\mathrm{a}}$ & .967 & .966 & 307.7092 \\
\hline
\end{tabular}

a. Predictors: (Constant), Time, Interest_Rate, Salary

b. Dependent Variable: Mortgages 
Table 2.

ANOVA $^{\text {a }}$

\begin{tabular}{|ll|r|r|r|r|l|}
\hline Model & & \multicolumn{1}{c|}{$\begin{array}{c}\text { Sum of } \\
\text { Squares }\end{array}$} & \multicolumn{1}{c|}{ df } & Mean Square & \multicolumn{1}{c|}{$\mathrm{F}$} & \multicolumn{1}{c|}{ Sig. } \\
\hline 1 & Regression & 392235269.7 & 3 & 130745089.9 & 1380.843 & $.000^{\mathrm{b}}$ \\
& Residual & 13350581.56 & 141 & 94684.976 & & \\
& Total & 405585851.2 & 144 & & & \\
\hline
\end{tabular}

a. Dependent Variable: Mortgages

b. Predictors: (Constant), Time, Interest_Rate, Salary

Table 3.

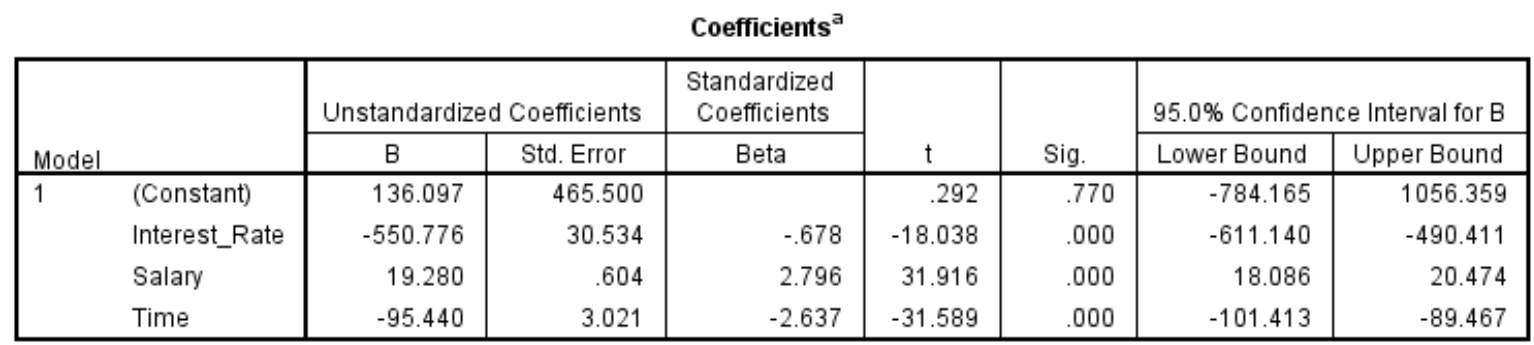

a. Dependent Variable: Mortgages

\section{Normal P-P Plot of Regression Standardized Residual}

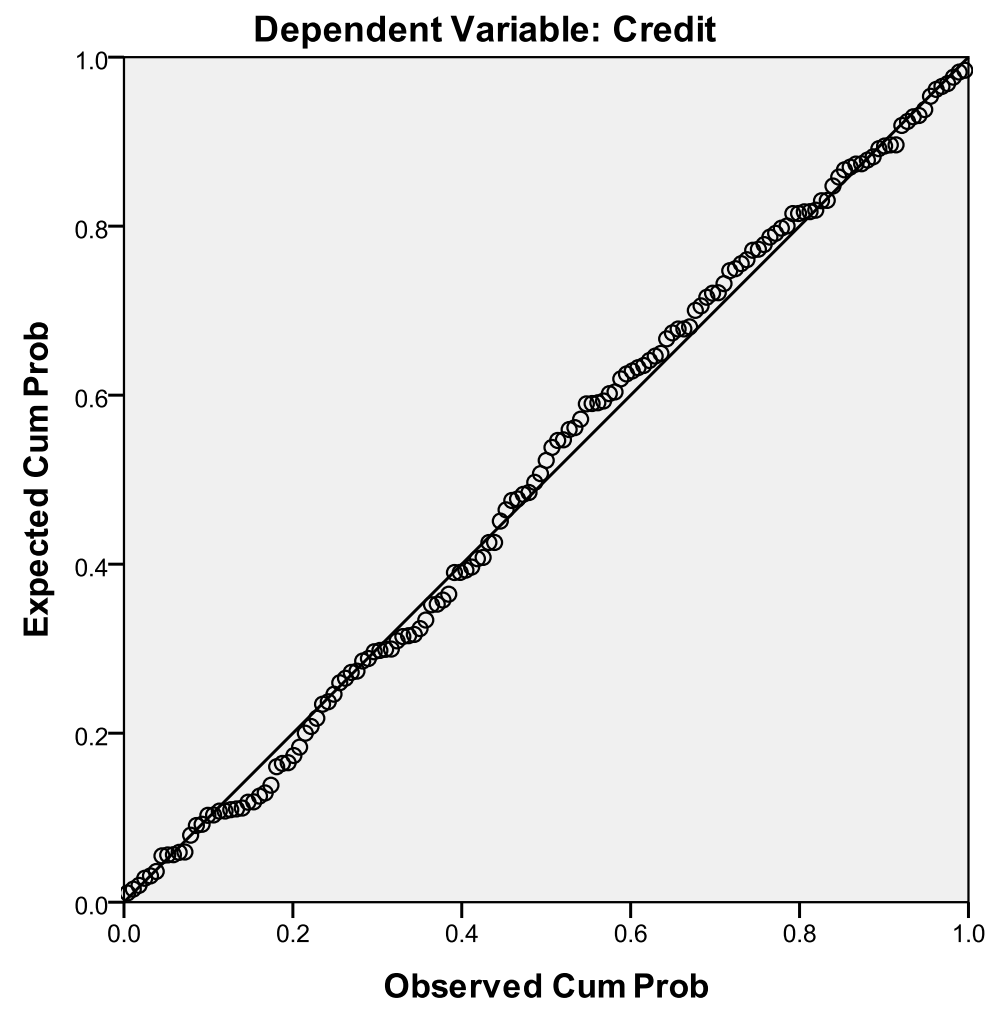

Figure 3. Normal Probability Plot of the Residuals 


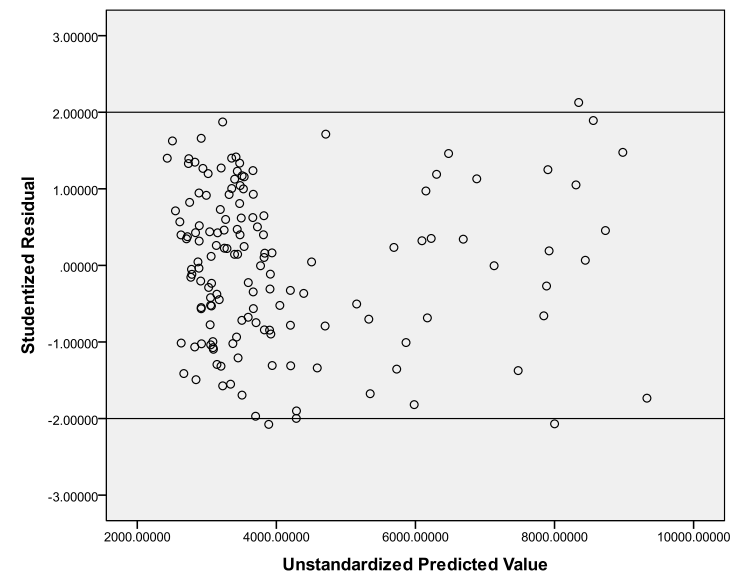

Figure 4. Stundentized Residuals vs. Predicted Values

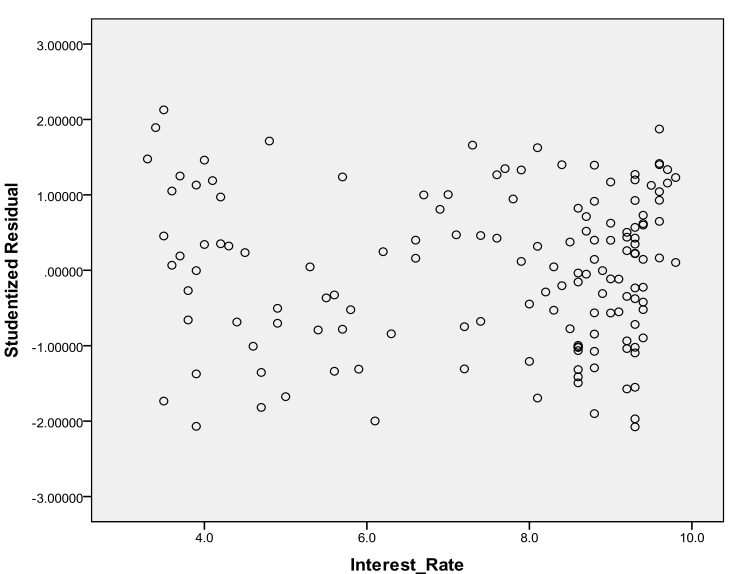

Figure 5. Stundentized Residuals vs. Interest_Rate

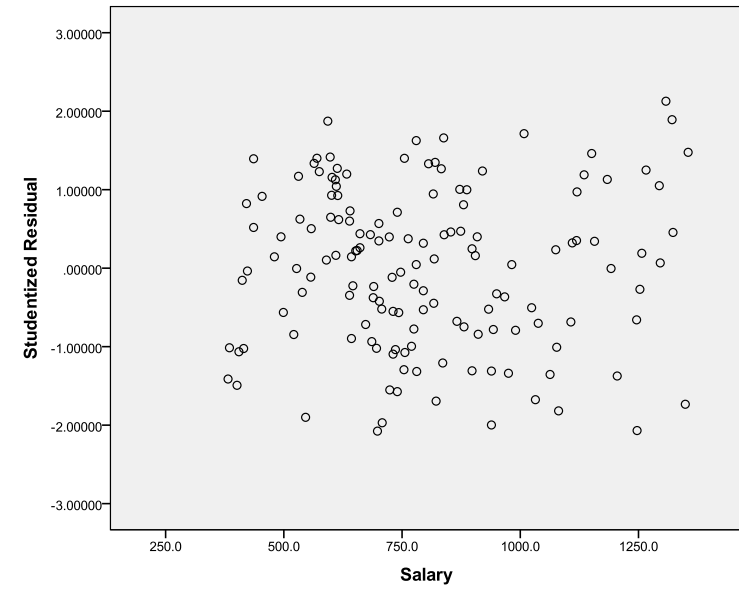

Figure 6. Stundentized Residuals vs. Salary

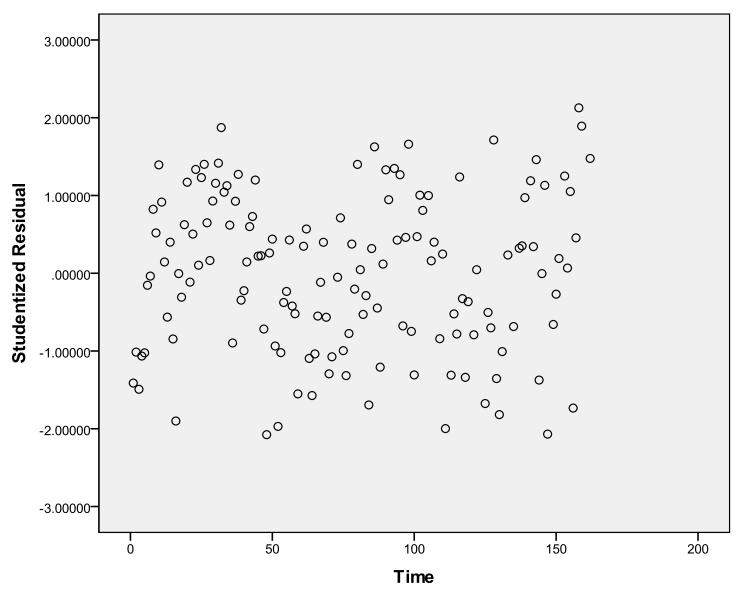

Figure 7. Stundentized Residuals vs. Time

Based on a residual analysis, the model appears adequate. From the "Normal Probability Plot of the Residuals", almost all observations are on the 45 degree line. Therefore, error terms follow a Normal Distribution. From the "Stundentized Residuals vs. Predicted Values" graph three values go beyond \pm 2 standard deviation reference lines, which means that these values are potential outliers. However, their effects are not large since they are within \pm 3 standard deviation reference lines and very close to \pm 2 standard deviation reference lines. From the same graph "Stundentized Residuals vs. Predicted Values", we do not observe any particular pattern in the data. Therefore, we satisfy the assumptions of Independence. To investigate further, we need to look at the Residuals vs. each independent variable. From the "Stundentized Residuals vs. Interest_Rate" graph, we observe that there is no change in variance and this is not an indication of potential violation of homoscedasticity. The similar results we observe from the "Stundentized Residuals vs. Salary" graph. There is no change in variance and this is an indication of homoscedasticity. The "Stundentized Residuals vs. Time" graph shows no pattern around the horizontal axis, and then the serial correlation is not present. The model appears adequate, therefore we can make the following inferences:

- $96.7 \%$ of the variation in mortgage debt can be explained by variation in mortgage interest rate, salary and time $\left(\mathrm{R}^{\wedge} 2=0.967\right)$.

- There is evidence of a relationship between Mortgage Debt and chosen independent 
variables $(F=1380.843, p$-value $=0.000)$ at the any level of significance $(\alpha=1 \%$, $5 \%$, or $10 \%)$.

- At the any level of significance ( $\alpha=1 \%, 5 \%$, or $10 \%)$, mortgage interest rate makes a significant contribution and should be included in the model $(\mathrm{t}=-18,038$, $\mathrm{p}$-value $=$ 0.000).

- At the any level of significance $(\alpha=1 \%, 5 \%$, or $10 \%)$, salary makes a significant contribution and should be included in the model $(\mathrm{t}=31.916$, $\mathrm{p}$-value $=0.000)$.

- At the any level of significance $(\alpha=1 \%, 5 \%$, or $10 \%)$, time makes a significant contribution and should be included in the model $(\mathrm{t}=-31.589, \mathrm{p}$-value $=0.000)$. equation as

Based on the above results, using the estimates (Table 3), we derive the estimated regression

Mortgage $=136.097 \_550.776$ Interest_Rate + 19.280 Salary -95.440 Time

that can be used to explain the impact of changes in independent variables on the dependent variable:

- If the Mortgage Interest Rate increases by $1 \%$, the Mortgage Debt is estimated to decrease by a mean of 550.78 million leva, holding all other factors constant.

- If the Salary increases by $1 \mathrm{lev}$, the Mortgage Debt is estimated to increase by a mean of 19.28 million leva, holding all other factors constant.

- Holding constant the effects of the Mortgage Interest Rate and the Salary, for every month increase in the time period, the Mortgage Debt is estimated to decrease by a mean of 95.44 million leva.

\section{Conclusion}

The results in this paper suggest that in Bulgaria the mortgage debt depend on salary and mortgage interest rate. The mortgage debt increases when the mortgage interest rate decreases. On the other hand, the household mortgage debt and salary go to the same direction. If average salary increases by $1 \mathrm{lev}$, then mortgage debt are predicted to increase by 19.28 million leva, holding mortgage interest rate constant for the particular period of month. The regression coefficient of mortgage interest rate implies that a one percentage point increase in the interest rate leads to a predicted decrease in mortgage debt of 550.78 million leva, holding the salary constant for the particular period of month.

This research offers the evidence for how mortgage interest rate and salary affect the mortgage debt in Bulgaria. The current study has important government policy implications, because policies designed to encourage or not the mortgage debt will have an impact on future economic growth through their impact on the household consumption and saving.

\section{References}

1. Bulgarian National Bank (2020) Economic Review. Sofia: Bulgarian national bank. Available at: http://bnb.bg/bnbweb/groups/public/documents/bnb_publication/pub_ec_r_2020_02_en.pdf (Accessed: 20 October 2020).

2. Bulgarian Bational (2020) Available at: https://www.bnb.bg/Statistics/StMonetaryInterestRate/StInterestRate/StIRInterestRate/index.htm (Accessed: 20 October 2020).

3. Calza, A., Monacelli, T. and Stracca, L. (2013) 'Housing Finance and Monetary Policy', Journal of the European Economic Association, 11(s1), pp. 101-122. doi: 10.1111/j.1542-4774.2012.01095.x.

4. Campbell, John Y. (2013) 'Mortgage Market Design', Review of Finance, European Finance Association, 17(1), pp. 1-33. doi: 10.3386/w18339.

5. Fan, Y. and Yavas, A. (2020) 'How Does Mortgage Debt Affect Household Consumption? Micro 
Evidence from China', Real Estate Economics, 48(1), pp. 43-88. doi: 10.1111/1540-6229.12244.

6. Karadimova, D. (2018) 'The Factors that Impact the Housing Prices in Bulgaria: Cross-Spectral Analysis', Izvestia na Sayuza na uchenite - Varna. Varna (Ikonomicheski nauki), 7(2), pp. 184 - 191.

7. Mavrov, H. (2011) 'Global Financial Crisis and Housing Market in Bulgaria', Izvestia na Ikonomicheskia universitet- Varna. Varna, (3), pp. 18 - 29.

8. Milinov, V., Angelov, P. and Zarkova, S. (2018) 'Assessment of the Impact of the Global Economic Crisis on the Real Estate Market of the European Union Members (Example from Bulgaria and Greece)', Almanah nauchni izsledvania, yubileyno izdanie. Svishtov, 26, pp. 107-135.

9. National Statistical Institute. Infostat (2020) https://infostat.nsi.bg/infostat/pages/reports/result.jsf?x_2=1053 (Accessed: 20 October 2020).

10. Zator, M. (2020) Working More to Pay the Mortgage: Interest Rates and Labor Supply. Available at: https://drive.google.com/file/d/1qXFy2YGnrReMqxBg1Qj5f_yNsOTp2Z_Z/view (Accessed: 20 October 2020). 